Article

\title{
Suggestions for Revegetation over the Next 30 Years Based on Precipitation in the Three North Region of China
}

\author{
Yu Xiao ${ }^{1,2, *}$, Gaodi Xie ${ }^{1,2}$, Chunxia Lu ${ }^{1,2}$, Changshun Zhang ${ }^{1,2}{ }^{-1}$, Jie Xu ${ }^{3}$, Jingya Liu ${ }^{1,2}$, Keyu Qin ${ }^{1,4}$, \\ Yiqiu Li ${ }^{5}{ }^{(-)}$, Chaoxuan $\mathrm{Xu}^{6}$, Caixia Zhang ${ }^{1}$, Yangyang Wang ${ }^{1,2}$, Shuang Gan ${ }^{1,2}$, Jia Liu ${ }^{1,2}$ and Liqiang Ge ${ }^{7}$ \\ 1 Institute of Geographical Sciences and Natural Resources Research, Chinese Academy of Sciences, \\ Beijing 100101, China; xiegd@igsnrr.ac.cn (G.X.); lucx@igsnrr.ac.cn (C.L.); zhangcs@igsnrr.ac.cn (C.Z.); \\ liujy.17b@igsnrr.ac.cn (J.L.); qinkeyu@igsnrr.ac.cn (K.Q.); zhangcx.06b@igsnrr.ac.cn (C.Z.); \\ wangyy.18b@igsnrr.ac.cn (Y.W.); gans.17s@igsnrr.ac.cn (S.G.); liuj.20s@igsnrr.ac.cn (J.L.) \\ 2 College of Resources and Environment, University of Chinese Academy of Sciences, Beijing 100049, China \\ 3 School of Ecology and Nature Conservation, Beijing Forestry University, Beijing 100083, China; jiexu@bjfu.edu.cn \\ 4 Institute of Oceanology, Chinese Academy of Sciences, Qingdao 266071, China \\ 5 School of Geographic and Environments Sciences, Guizhou Normal University, Guiyang 550001, China; \\ yqiu.li@163.com \\ 6 ShaoXing Urban Planning and Design Institute, Shaoxing 312099, China; xcx71335@sohu.com \\ 7 National Research Center for Geoanalysis, Beijing 100037, China; geliqiang@mail.cgs.gov.cn \\ * Correspondence: xiaoy@igsnrr.ac.cn; Tel.: +86-10-6488-8157
}

Citation: Xiao, Y.; Xie, G.; Lu, C.; Zhang, C.; Xu, J.; Liu, J.; Qin, K.; Li, Y.; Xu, C.; Zhang, C.; et al. Suggestions for Revegetation over the Next 30 Years Based on Precipitation in the Three North Region of China. Sustainability 2021, 13, 12649. https:/ / doi.org/10.3390/su132212649

Academic Editor: Agostina Chiavola

Received: 22 October 2021

Accepted: 13 November 2021

Published: 16 November 2021

Publisher's Note: MDPI stays neutral with regard to jurisdictional claims in published maps and institutional affiliations.

Copyright: (c) 2021 by the authors. Licensee MDPI, Basel, Switzerland. This article is an open access article distributed under the terms and conditions of the Creative Commons Attribution (CC BY) license (https:// creativecommons.org/licenses/by/ $4.0 /)$.

\begin{abstract}
Afforestation in the Three North Region (TNR) of China has received wide concern due to the low survival rate and threats to water security associated with the lack of available precipitation for vegetation. It is crucial to provide a spatial layout for revegetation according to the available precipitation to achieve the vegetation cover target. This study investigated the spatial pattern of precipitation, determined the suitable vegetation distribution based on the ecological water requirements and precipitation, and proposed an optimized revegetation scheme by comparing the actual and suitable vegetation patterns. The results indicated that the actual vegetation that matched the pixel-level precipitation accounted for $67.24 \%$ of the total vegetation area in the TNR. However, $18.50 \%$ of the actual forest, $21.82 \%$ of the actual shrublands, and $19.95 \%$ of the actual grasslands were overloaded with respect to precipitation. The total suitable vegetation area was reduced slightly compared to the actual vegetation area. There is still some potential for the revegetation of forest and shrublands, mainly those in the eastern and south-eastern parts of the TNR. The optimized revegetation area in the TNR was $3.04 \times 10^{6} \mathrm{~km}^{2}$, including a maintenance management type of $2.19 \times 10^{6} \mathrm{~km}^{2}$, an upgrade type of $0.49 \times 10^{6} \mathrm{~km}^{2}$, and a degradation type of $0.37 \times 10^{6} \mathrm{~km}^{2}$. Maintenance management (natural restoration) and transformation to vegetation types with lower ecological water requirements were recognized as important revegetation practices in the TNR. This study provides guidelines to adjust the Three North Shelterbelt Project policies based on precipitation data to reduce the negative impact of revegetation on the hydrological cycle.
\end{abstract}

Keywords: precipitation; threshold; optimizing scheme; the Three North Shelterbelt Program

\section{Introduction}

Desertification is the most critical challenge facing arid and semiarid areas worldwide. Many countries have adopted afforestation to mitigate desertification, such as the Great Plains Shelterbelt [1], the Great Stalin Plan for the Transformation of Nature [2], and the Great Green Wall of the Sahara [3,4]. Desertification in northern China is still severe, with natural and anthropogenic causes, such as arid or semiarid climates, over-grazing, logging, and crop planting [5-8]. Currently, several programs, such as the Three North Shelterbelt Program (TNSP), the Grain for Green Program, and the Natural Forest Protection program, have been initiated to combat desertification in Northern China [9,10]; among them, the TNSP is the most ambitious program with the largest extent and the longest time span. 
The TNSP has been implemented for more than 40 years [11]. Wang et al. [12] argued that desertification in the arid region in northern China improved overall but deteriorated locally from 2000 to 2015 based on MODIS data. Gerlein-Safdi et al. [13] claimed that vegetation biomass in China's TNSP has been increasing, and reforestation could increase ecosystem productivity and decrease desertification. Cao et al. [14] showed that the establishment of fruit plantations in the TNSP produced $235.5 \times 10^{9} \mathrm{RMB} /$ year, while the benefits of natural recovery of vegetation were estimated to be $447.43 \times 10^{9} \mathrm{RMB} /$ year. The contribution rates of shelterbelts in the TNSP were calculated to be $4.28-9.45 \%$ among different climatic potential productivity zones [15].

However, the TNSP has received the most attention among ecological restoration projects in China $[6,16,17]$. It was reported that China had completed $46.1 \times 10^{6} \mathrm{hm}^{2}$ afforestation by 2017 in the Three North Region (TNR). However, only $60 \%$ of the planted trees or shrubs were kept, and only $46.9 \%$ of the trees and shrubs developed into a forest [18]. Water scarcity was recognized as the most important reason for the loss [19]. With insufficient water availability, the planted trees usually prematurely aged, as evidenced by decreasing growth rates, top withering, dead stems, etc. [20,21]. Moreover, afforestation without considering water availability imposed passive impacts on water resources and the hydrological cycle in arid and semiarid climate zones [10,16,22]. Cao et al. [14] indicated that afforestation of the TNSP in areas with insufficient precipitation to sustain tree growth would cause a rapid drop in groundwater level, which would degrade the ecosystem in arid and semiarid regions [23].

According to the components of a water budget (precipitation, irrigation, evapotranspiration, storage change, and discharge), vegetation can grow when water input (precipitation and irrigation) is higher than water output (evapotranspiration and discharge). In arid and semiarid regions, groundwater and surface water can scarcely be used for vegetation irrigation, as the priority of water use for vegetation is lower than that for households, industry, and agriculture [22]. Precipitation available for vegetation in the TNR is precipitation after subtracting discharge (surface runoff and percolation) and storage change (regarded as zero) [24-27]. However, due to neglecting the available precipitation in the early stage of the TNSP, numerous planted trees in the TNR still survived by irrigation or by depletion of groundwater; otherwise, these trees suffer from premature ageing $[20,25]$. Sustaining tree plantations has become an economic burden for the local community due to irrigation water fees and the risk to socioeconomic water security and sustainable development $[28,29]$. Therefore, it is critical to clarify where the ecological water requirement of the actual vegetation exactly matched or did not match the available precipitation in the TNR and to support suitable recommendations for improvement.

Furthermore, revegetation in the TNR will continue to be implemented by the government to mitigate desertification and improve the livelihood of local farmers in the next 30 years [11,24]. Revegetation based on available precipitation has been recognized as the most important principle for vegetation development in the TNR [9]. Shrubs and grassland were also recruited in revegetation, which contributed to vegetation cover increases with lower water requirements than trees [7,27]. Nevertheless, there is still no clear plan for the spatial layout of revegetation of the TNSP that assimilates the available precipitation for vegetation and recruitment of shrubs and grassland [25-27].

This paper calculated the available precipitation for vegetation at the pixel level with the water balance equation, determined the suitable vegetation distribution based on the ecological water requirements for vegetation in different climate zones, assessed the suitability of actual vegetation by comparing it with the suitable vegetation pattern, and proposed the optimization scheme of revegetation in the next 30 years. This study attempts to answer several key questions of revegetation about the TNSP in the future: (1) Does actual vegetation spatially match the suitable vegetation determined by available precipitation? (2) Is there a broader scope for revegetation? (3) How can we do revegetation in the future? 


\section{Materials and Methods}

\subsection{Study Area}

The TNR includes the north-western, central north, and north-eastern parts of China, covering 13 provinces. The total area of the TNR is 4.49 million square kilometers, which accounts for approximately $46.79 \%$ of China's landmass (Figure 1 ). It is situated between $33^{\circ} 50^{\prime} \mathrm{N}-53^{\circ} 33^{\prime} \mathrm{N}$ latitude and $73^{\circ} 33^{\prime} \mathrm{E}-135^{\circ} 05^{\prime} \mathrm{E}$ longitude. The altitude ranged from -160 to $7365 \mathrm{~m}$. The climate shifts from humid in the east to semiarid and arid in the west. The average annual precipitation decreases from $625 \mathrm{~mm}$ in the east to $109 \mathrm{~mm}$ in the west. The land cover types include forest (12.07\%), grassland $(29.93 \%)$, cropland $(15.35 \%)$, settlement $(1.61 \%)$, wetland $(4.39 \%)$, and barren and sparse vegetation land $(36.65 \%)$ in reference to a $1 \mathrm{~km}$ land use/cover distribution map [30].

The TNSP was designed to protect the forest ecosystem and increase forestland cover in the TNR [14]. It has been implemented since 1978 and is planned to be finished in 2050, lasting over 70 years and divided into three stages (1978-2000, 2001-2020, and 2021-2050) [11]. At the end of 2018, the afforestation area was more than 30 million hectares, and the ratio of vegetation cover to land increased from $5.05 \%$ in 1978 to $13.57 \%$ in 2018 [31].

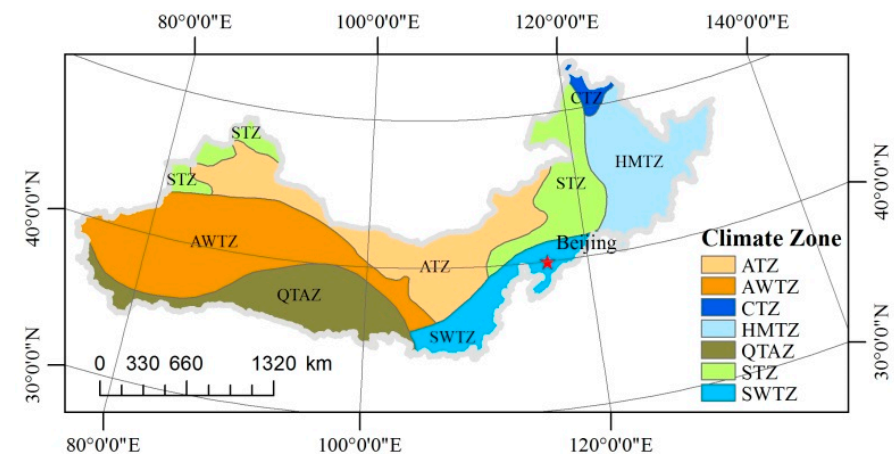

(a) Climate zones

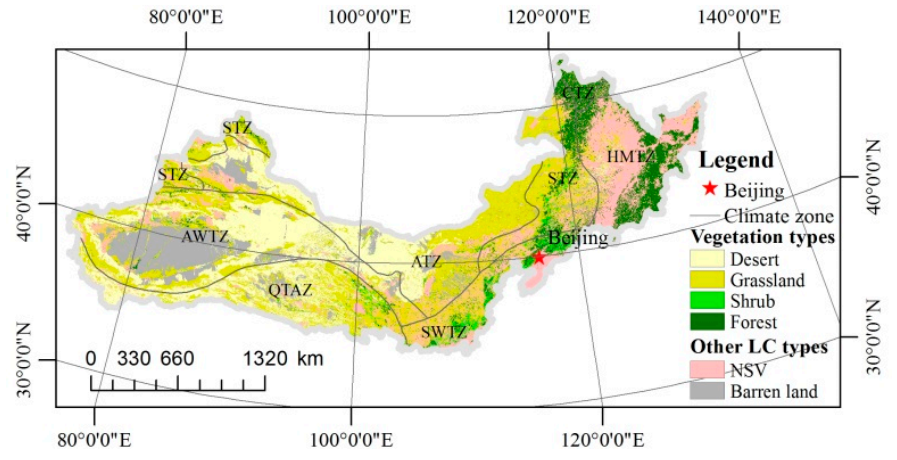

(b) Vegetation

Figure 1. Climate zones (a) and actual vegetation (b) of the TNR. ATZ: arid temperate zone; AWTZ: arid warm temperate zone; CTZ: cold temperate zone; HMTZ: humid mid-temperate zone; QTAZ: Qinghai-Tibet alpine zone, STZ: Semi-arid temperate zone; SWTZ: semi-humid warm temperate zone; LC: Land cover; NSV: not suitable for vegetation (the same as below).

\subsection{Framework of Optimizing the Spatial Distribution of Revegetation}

The optimization scheme for spatial distribution of revegetation in the TNR was determined based on the precipitation, EWR threshold, and actual land cover pattern at the pixel level (Figure 1).

First, the gridded APV was calculated from 1980 to 2018 and from 2019 to 2049 with gridded precipitation from 1980 to 2018 and from 2019 to 2049, respectively. This paper adopted the $50 \%$ accumulation frequency as the precipitation of each meteorological station with Hydrological Frequency Distribution Curve Fitting software (HFDCF, teaching version) by PE3 (Pearson III) as the best-fit model [32,33]. The annual precipitation from 2019 to 2049 was simulated with the autocorrelation regressive integrated moving average (ARIMA) model [34]. The precipitation data were interpolated in ArcGIS with the cokriging interpolation method incorporating the DEM data with cross-validation using a crossvalidation tool in ArcGIS [35,36].

Second, the paper combined the gridded APV from 1980 to 2018 and 2019 to 2049 to obtain the gridded LAPV. According to the four components of the water budgets (precipitation, evapotranspiration, storage change, and discharge) [37-39], water resources from precipitation that are available for vegetation growth can be calculated by subtracting storage change and discharge from the total precipitation [40]. The discharge includes surface runoff, subsurface runoff, and percolation. In the TNR, the storage change is nearly 0 within one year, and there is almost no subsurface runoff [41]. The available annual precipitation for vegetation was computed with the annual precipitation, subtracting 
annual surface runoff and annual percolation. The surface runoff and percolation were estimated with their ratios to annual precipitation obtained from the in situ data of the climax community of different climate zones (Table 1).

Table 1. Ratios of surface runoff and percolation to annual precipitation in the TNR.

\begin{tabular}{|c|c|c|c|c|}
\hline Climate Zones & Climax Community & Dominant Species & $\begin{array}{c}\text { Ratios of } \\
\text { Surface Runoff } \\
\text { to Precipitation (\%) }\end{array}$ & $\begin{array}{c}\text { Ratios of Percolation } \\
\text { to Precipitation (\%) }\end{array}$ \\
\hline $\begin{array}{l}\text { Semi-humid warm } \\
\text { temperate zone }\end{array}$ & $\begin{array}{l}\text { Deciduous } \\
\text { Broadleaf Forest }\end{array}$ & $\begin{array}{c}\text { Quercus wutaishanica } \\
\text { Blume, Betula platyphylla } \\
\text { Suk., Robinia pseudoacacia } \\
\text { Linn., Populus davidiana } \\
\text { Dode, etc. }\end{array}$ & $1.31 *$ & 12.76 㧊 \\
\hline $\begin{array}{l}\text { Arid warm } \\
\text { temperate zone }\end{array}$ & Shrubs, desert & $\begin{array}{l}\text { Festuca ovina Linn., } \\
\text { Geranium wilfordii } \\
\text { Maxim., Alchemilla } \\
\text { tianshanica Juz., etc. }\end{array}$ & $2.96^{\dagger}$ & $1.05 \S \S$ \\
\hline $\begin{array}{c}\text { Humid } \\
\text { mid-temperate zone }\end{array}$ & $\begin{array}{l}\text { Deciduous coniferous } \\
\text { and broad-leaved } \\
\text { mixed forest, } \\
\text { Deciduous } \\
\text { Broadleaf Forest }\end{array}$ & $\begin{array}{c}\text { Pinus koraiensis } \\
\text { Siebold et Zuccarini, } \\
\text { Larix gmelinii (Ruprecht) } \\
\text { Kuzeneva, Betula } \\
\text { platyphylla Suk., Tilia } \\
\text { mandshurica Rmpr.et } \\
\text { Maxim., Quercus } \\
\text { mongolica Fischer ex } \\
\text { Ledebour, etc. }\end{array}$ & $1.38 \ddagger$ & 16.82 III \\
\hline $\begin{array}{c}\text { Semi-arid } \\
\text { temperate zone }\end{array}$ & Meadow, shrubs & $\begin{array}{c}\text { Stipa capillata Linn., } \\
\text { Hippophae rhamnoides } \\
\text { Linn., etc. }\end{array}$ & $2.30 \S$ & $11.46^{* * *}$ \\
\hline Arid temperate zone & Typical steppe & $\begin{array}{l}\text { Stipa Grandis P. Smirn., } \\
\text { Stipa krylovii Roshev., etc. }\end{array}$ & $1.43^{\mathbb{I I}}$ & $7.14^{+++}$ \\
\hline Cold temperate zone & $\begin{array}{c}\text { Deciduous } \\
\text { coniferous forest }\end{array}$ & Larix gmelinii & $0.36^{* *}$ & 16.39 抽 \\
\hline $\begin{array}{l}\text { Qinghai-Tibet } \\
\text { alpine zone }\end{array}$ & $\begin{array}{l}\text { Shrubs, subshrubs, } \\
\text { alpine deserts }\end{array}$ & $\begin{array}{c}\text { Carex, Kobresia } \\
\text { myosuroides (Villars) Foiri, } \\
\text { Polygonum viviparum } \\
\text { Linn., Potentilla fruticosa } \\
\text { Linn., etc. }\end{array}$ & $2.77^{+\dagger}$ & $34.92 \S \S \S$ \\
\hline
\end{tabular}

Note: The ratio of surface runoff/percolation to precipitation of each climate zone was computed as the average of ratios of different in situ studies in this climate zone. Sources of the ratios of surface runoff to precipitation: * $[42-46],{ }^{\dagger}[47],{ }^{\ddagger}[48-53], \$[54,55],{ }^{\mathbb{I}}[56-59],{ }^{* *}[51,60]$,

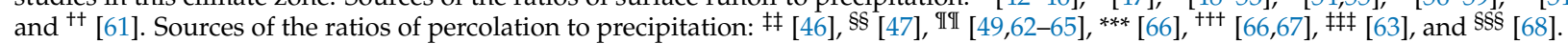

Third, integrated suitable vegetation in the TNR was produced with suitable vegetation based on LAPV and irrigation water. Suitable vegetation based on LAPV was produced based on the LAPV referring to the EWR threshold for natural vegetation of different climate zones. The suitable vegetation based on irrigation water was made with irrigation water availability and an EWR threshold. Irrigation water was calculated as $30 \%$ of the surplus water [69]. The surplus water was estimated by the balance of water supply and water consumption at the watershed level. Water supply was simulated with the InVEST model [70], while water consumption was estimated with land cover data and water consumption per hectare [71]. The vegetation EWR threshold was determined as the actual vegetation evapotranspiration at a $10 \%$ accumulation frequency among all grid cells from low to high in each climate zone. The actual vegetation evapotranspiration was calculated based on the vegetation potential evapotranspiration with Fu's equation [72,73].

Finally, this study compared gridded actual vegetation and gridded integrated suitable vegetation to assess the suitability of actual vegetation. The EWRs of different vegetation 
types in the same climate zone were as follows: forest $>$ shrubs $>$ grassland $>$ barren land. "Matching" means that actual vegetation is the same as suitable vegetation, "surplus" refers to the EWR of actual vegetation being lower than that of suitable vegetation, while "overloaded" means that the EWR of actual vegetation is higher than that of suitable vegetation. Accordingly, the optimization scheme for the spatial distribution of revegetation in the TNR includes the upgrade type (surplus type), maintenance management type (matching type), and degradation type (overloaded type) (Figure 2).

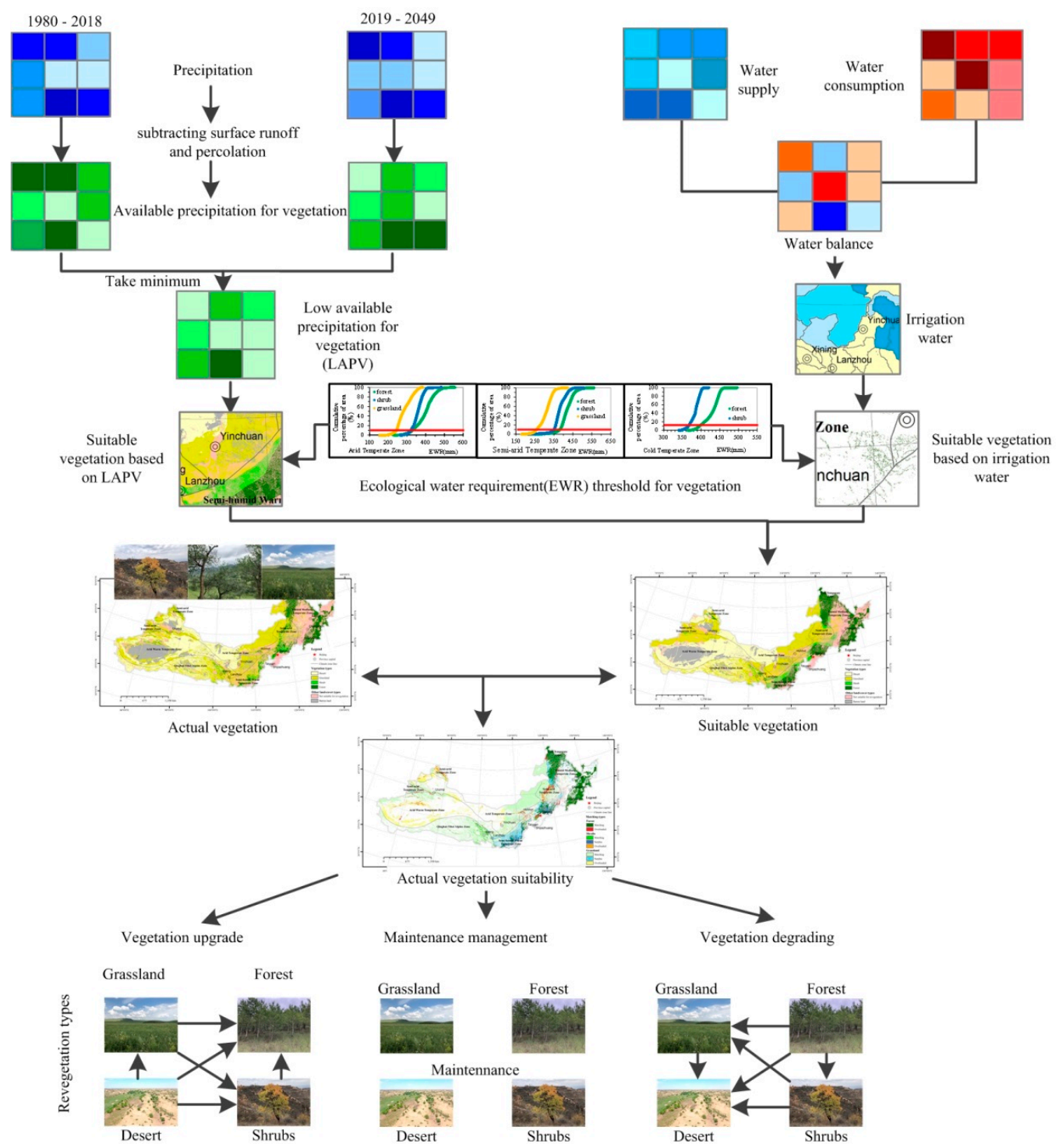

Figure 2. Framework of the optimization scheme for revegetation at the pixel level in the TNR. The rank of ecological water requirements (EWRs) of different vegetation types was as follows: forest $>$ shrubs $>$ grassland $>$ barren land. The "vegetation upgrade" type refers to the suitable vegetation type being forest while the actual vegetation type is shrubs, grassland or barren land, or the suitable vegetation is shrubs while the actual vegetation is grassland or barren land, and so on. The "maintenance management" type means that the actual vegetation type is the same as the suitable vegetation. The "vegetation degrading" type refers to the suitable vegetation type being grassland, while the actual vegetation type is forest or shrub, and so on.

For the upgrade type, actual vegetation can be converted to the vegetation types of higher EWR with an available precipitation surplus by closing hillsides to facilitate afforestation, planting, seeding, etc. The upgrade vegetation types include shrub to forest types, from grassland to shrubs, from desert to grassland, from grassland to forest, from 
desert to forest, and from desert to shrubs. The suitable vegetation type was the same as the actual vegetation type, and the most important practice was to limit human activities to maintain the management type. As the actual vegetation was unsustainable for the degradation type, the appropriate measure was to gradually return the vegetation types to those matching the available precipitation by gradually stopping irrigation, felling prematurely ageing trees, planting suitable shrub or grass, etc. The degradation vegetation type includes forest to shrubs, forest to grassland, forest to desert, shrubs to grassland, shrubs to desert, and grassland to desert.

\subsection{Data Sources and Pre-Processing}

The meteorological datasets were obtained from the National Meteorological Information Centre of China (http: / / data.cma.cn/,15/06/2019). The annual precipitation data of 729 stations in the TNR from 1951 to 2018 were adopted in this study. The land use/cover at $1 \times 1 \mathrm{~km}$ resolution in the TNR in 2015 is from the Chinese Land Use Change Database (CLUSD) [30]. The SRTM 90-m Digital Elevation Database was utilized. All of the gridded data processing, data spatial analyses, and calculations were conducted through ArcGIS v. 10.0 software (Environmental Systems Research Institute, Inc., Redlands, CA, USA). All data were resampled to a $1 \times 1 \mathrm{~km}$ grid to reduce uncertainties arising from data processing.

\section{Results}

\subsection{Spatial Pattern of Precipitation}

3.1.1. Precipitation at a 50\% Accumulation Frequency from 1980-2018

The precipitation at a 50\% accumulation frequency from 1980 to 2018 in the TNR decreased from southeast to northwest. The precipitation in the northeastern region was greater than that in the western regions due to the abundant water vapor brought by the Southeast Asian monsoon (Table 2). The precipitation in most areas of Northeast China, the Beijing-Tianjin-Hebei Metropolitan Area, and the eastern part of the Loess Plateau was more than $400 \mathrm{~mm}$. The 400-mm precipitation line was also the transition line between forests and grasslands in northern China. The more it expanded to the northwest, the lower the precipitation. The 200-mm precipitation line extended from the north of the Hunshandak Sands in Inner Mongolia towards the southwest to the eastern part of the Qinghai-Tibet Plateau. The $200-\mathrm{mm}$ precipitation line was considered the transition line between deserts and grasslands. The western part of the TNR experienced intense drought conditions, as the precipitation in most regions was lower than $200 \mathrm{~mm}$. Only the precipitation in the area surrounding Tianshan Mountain was slightly more than $200 \mathrm{~mm}$ (Figure 3).

Table 2. Annual precipitation at a 50\% accumulation frequency in the TNR.

\begin{tabular}{|c|c|c|c|}
\hline Climate Zones & Area $\left(10^{6} \mathrm{hm}^{2}\right)$ & $\mathrm{AP}(\mathrm{mm})$ & PP (mm) \\
\hline Arid Warm Temperate Zone & 121.78 & $90.58 \pm 69.49$ & $137.81 \pm 94.96$ \\
\hline Cold Temperate Zone & 6.26 & $453.18 \pm 37.62$ & $499.78 \pm 53.31$ \\
\hline Humid Medium Temperate Zone & 64.91 & $550.83 \pm 107.03$ & $649.62 \pm 132.68$ \\
\hline Semi-humid Warm Temperate Zone & 38.91 & $485.79 \pm 60.43$ & $542.60 \pm 98.27$ \\
\hline Arid Temperate Zone & 87.89 & $189.79 \pm 81.61$ & $254.01 \pm 107.11$ \\
\hline Qinghai-Tibet Alpine Zone & 68.19 & $143.74 \pm 131.54$ & $227.74 \pm 175.64$ \\
\hline Semi-arid Temperate Zone & 61.43 & $325.88 \pm 76.50$ & $382.30 \pm 109.76$ \\
\hline
\end{tabular}

Note: AP: Actual Precipitation is the precipitation at a 50\% accumulation frequency from 1980 to 2018 ; PP: Predicted Precipitation is the predicted precipitation at a 50\% accumulation frequency from 2019 to 2049 . All precipitation data are presented as the means \pm standard deviation (SD). 


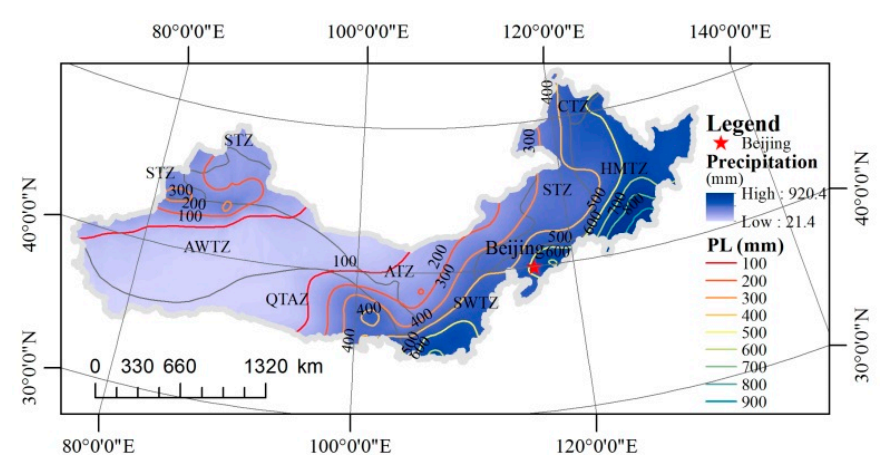

(a) Actual Precipitation

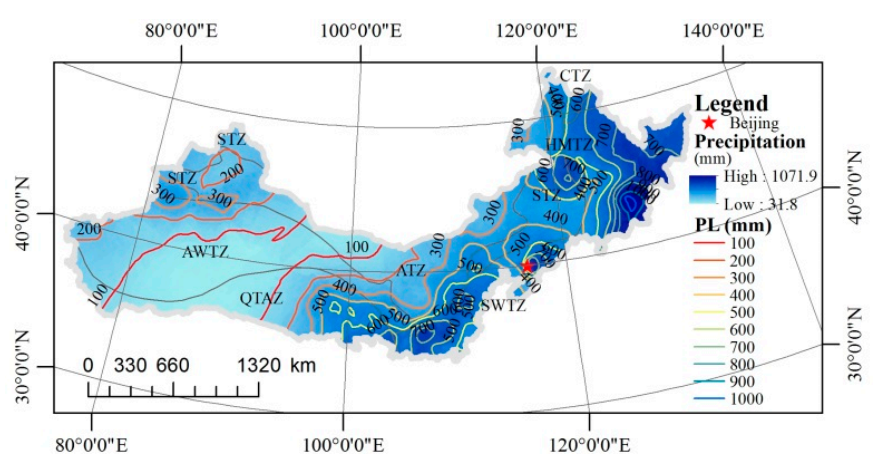

(b) Predicted Precipitation

Figure 3. Spatial pattern of actual (a) and predicted (b) annual precipitation at a 50\% accumulation frequency and its contours. PL is the precipitation line. Actual annual precipitation is the annual precipitation with a $50 \%$ accumulation frequency from 1980 to 2018; PP: Predicted annual precipitation is the predicted precipitation at a $50 \%$ accumulation frequency from 2019 to 2049.

\subsubsection{Precipitation at a $50 \%$ Accumulation Frequency in Next 30 Years}

According to the ARIMA simulation, the precipitation at a 50\% accumulation frequency from 2019 to 2049 in most of the TNR increased compared to the precipitation at a $50 \%$ accumulation frequency from 1980 to 2018 (Table 2). The precipitation in the Horqin Sandy Land of eastern Inner Mongolia, northern Xinjiang, and northern Shaanxi increased significantly. The $400-\mathrm{mm}$ precipitation line generally moved towards the northwest. However, the 400-mm precipitation line in south-eastern Inner Mongolia and western Hebei moved southeast. The area with precipitation lower than $200 \mathrm{~mm}$ in the western region of the TNR decreased (Figure 3).

\subsection{Spatial Pattern of Available Precipitation for Vegetation}

Based on the precipitation accumulation frequency of 50\% from 1980 to 2018, the average actually available precipitation for vegetation (AAPV) among different climate zones in the TNR was estimated to range from 88.61 to $450.73 \mathrm{~mm}$. The AAPVs of the humid medium temperate zone, the semihumid warm temperate zone, and the cold temperate zone were much higher than those of other climate zones (Table 3 and Figure 4). The AAPV of the arid warm temperate zone was lower than $90 \mathrm{~mm}$, which was deficient for vegetation growth. Based on predicted precipitation with a 50\% accumulation frequency from 2019 to 2049, the average predicted available precipitation for vegetation (PAPV) was calculated to range from 121.22 to $523.54 \mathrm{~mm}$. The PAPV of most areas was higher than the AAPV but lower in Tianshan Mountain of Xinjiang Province, Liaohe Basin in Liaoning Province, and the southern part of the Loess Plateau in Shaanxi Province. The low available precipitation for vegetation (LAPV) was the average lowest amount of precipitation between the AAPV and PAPV at the pixel level. The LAPV of each climate zone was lower than both the AAPV and PAPV (Table 3 and Figure 4).

Table 3. Available precipitation for vegetation in the TNR.

\begin{tabular}{ccccc}
\hline Climate Zones & Area $\mathbf{( 1 0}^{\mathbf{6}} \mathbf{h m}^{\mathbf{2}} \mathbf{)}$ & AAPV $(\mathbf{m m})$ & PAPV $(\mathbf{m m})$ & LAPV $(\mathbf{m m})$ \\
\hline Arid Warm Temperate Zone & 121.78 & $88.61 \pm 66.87$ & $121.22 \pm 82.41$ & $88.16 \pm 65.53$ \\
Cold Temperate Zone & 6.26 & $377.29 \pm 31.30$ & $409.16 \pm 44.52$ & $376.79 \pm 31.63$ \\
Humid Medium Temperate Zone & 64.91 & $450.73 \pm 87.53$ & $523.54 \pm 97.12$ & $444.83 \pm 85.52$ \\
Semi-humid Warm Temperate Zone & 38.91 & $417.65 \pm 51.92$ & $468.42 \pm 60.26$ & $413.9 \pm 50.38$ \\
Arid Temperate Zone & 87.89 & $179.10 \pm 74.00$ & $233.17 \pm 92.28$ & $178.75 \pm 73.95$ \\
Qinghai-Tibet Alpine Zone & 68.19 & $105.84 \pm 88.78$ & $158.60 \pm 116.56$ & $104.68 \pm 86.91$ \\
Semi-arid Temperate Zone & 61.43 & $283.35 \pm 65.27$ & $319.87 \pm 81.23$ & $280.70 \pm 63.97$ \\
\hline
\end{tabular}

Note: AAPV: Actually Available Precipitation for Vegetation; PAPV: Predicted Available Precipitation for Vegetation; LAPV: Low Available Precipitation for Vegetation, calculated as the average lowest precipitation amount between the AAPV and PAPV of each pixel. All precipitation data are presented as the means \pm standard deviation (SD). 


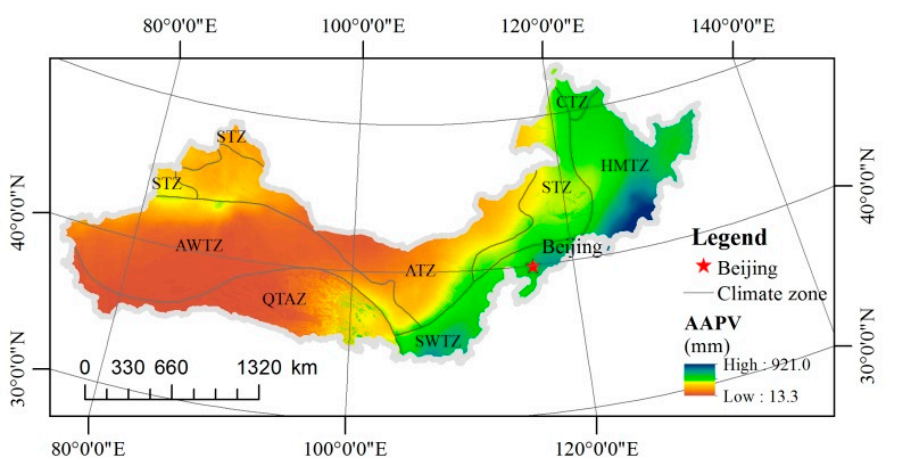

(a) AAPV

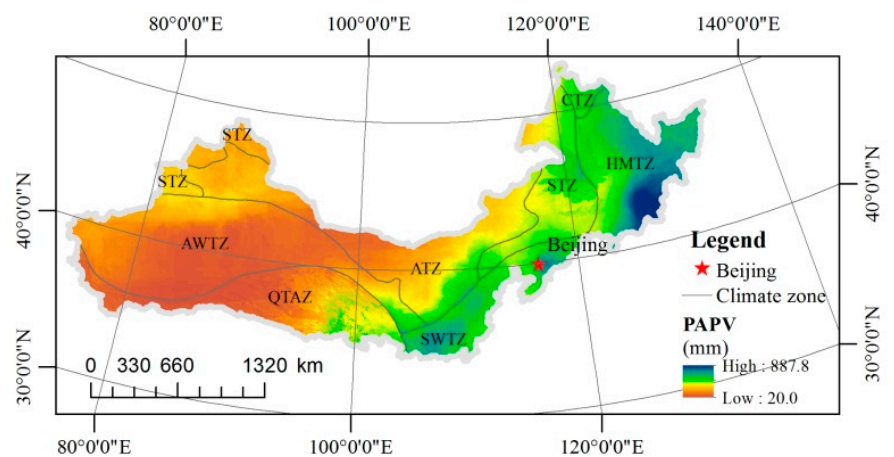

(b) PAPV

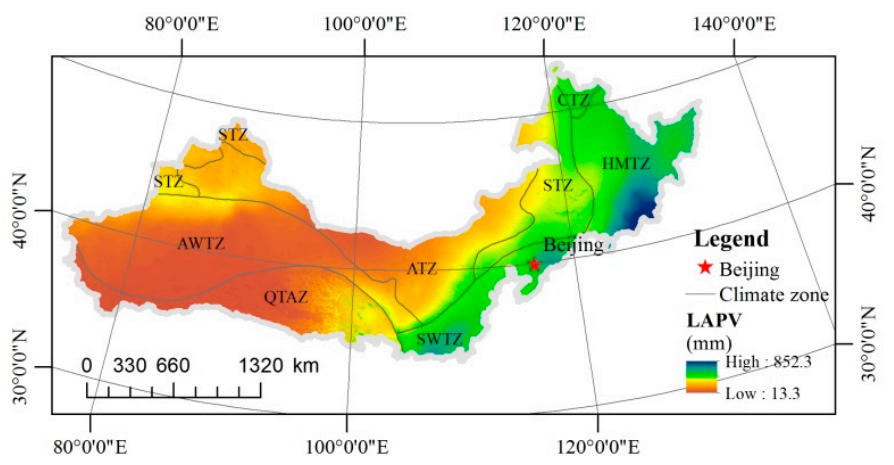

(c) LAPV

Figure 4. Spatial pattern of available precipitation for vegetation in the TNR. (a). AAPV: Actually Available Precipitation for Vegetation; (b). PAPV: Predicted Available Precipitation for Vegetation; (c). LAPV: Low Available Precipitation for Vegetation, calculated as the average lowest precipitation amount between the AAPV and PAPV of each pixel.

\subsection{Irrigation Water for Green Infrastructures of Communities}

Runoff from precipitation should preferentially be consumed by agriculture, industry, and households, and then ensure the river ecological function. Next, the surplus water from runoff can be used to irrigate the green infrastructures of communities. Only 47 of 100 subbasins in the TNR supported irrigation water for green infrastructures. The total water available for irrigation was estimated to be $57.01 \times 10^{9} \mathrm{~m}^{3}$. The average amount of water used to irrigate green infrastructures ranged from 2.90 to $70.99 \mathrm{~mm}$. The subbasins with surplus water available for green infrastructure irrigation were mainly located in areas of Inner Mongolia Province, the southern part of Jilin Province, the northern and western part of Hebei Province, the eastern part of Shanxi Province, and the eastern and northern part of Xinjiang Province (Figure 5).

\subsection{Threshold of Ecological Water Requirement for Vegetation}

According to Penman's equation, the EWR for vegetation ranged from 18.96 to $712.03 \mathrm{~mm}$. Spatially, the EWR in Northeast China, the Beijing-Tianjin-Hebei region, the southern part of the Loess Plateau in Shaanxi Province, and the Yili River Valley in Xinjiang Province was much higher than that in other areas. With a higher leaf area and higher level of actual evapotranspiration, more trees resulted in a higher EWR in these areas. As the actual vegetation evapotranspiration at a $10 \%$ accumulation frequency among all grid cells from low to high for different types of vegetation in each climate zone, the EWRT of different vegetation types in the semihumid warm temperate zone and the humid medium temperate zone were higher than those in the arid temperate zone, the arid warm temperate zone, and the Qinghai-Tibet alpine zone (Table 4). The possible reason could be the leaf area of the tree species, and that the growth rates in the semi-humid warm temperate zone and the humid medium temperate zone were much higher. 


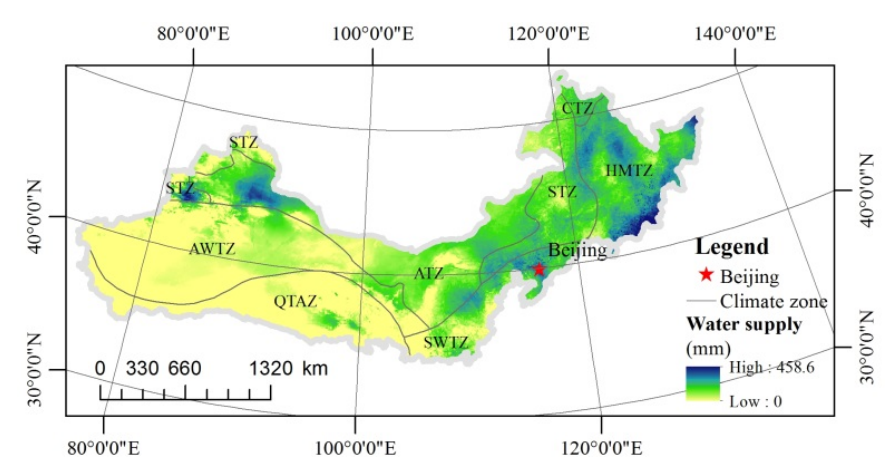

(a) water supply

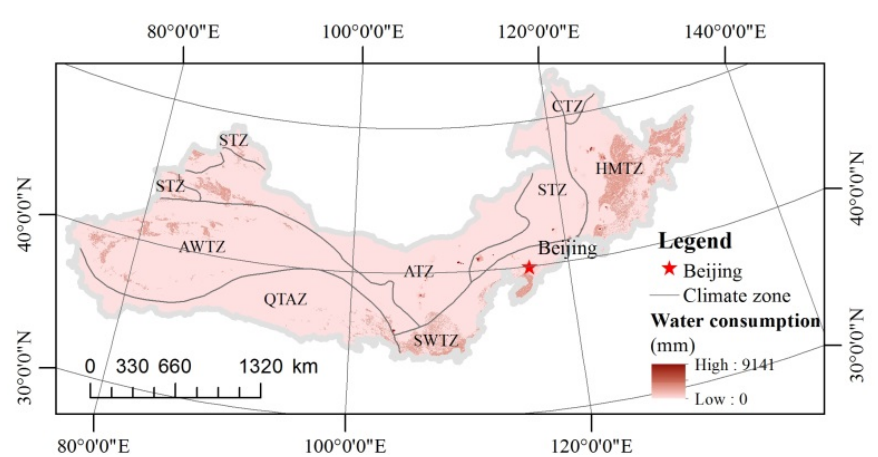

(b) water consumption

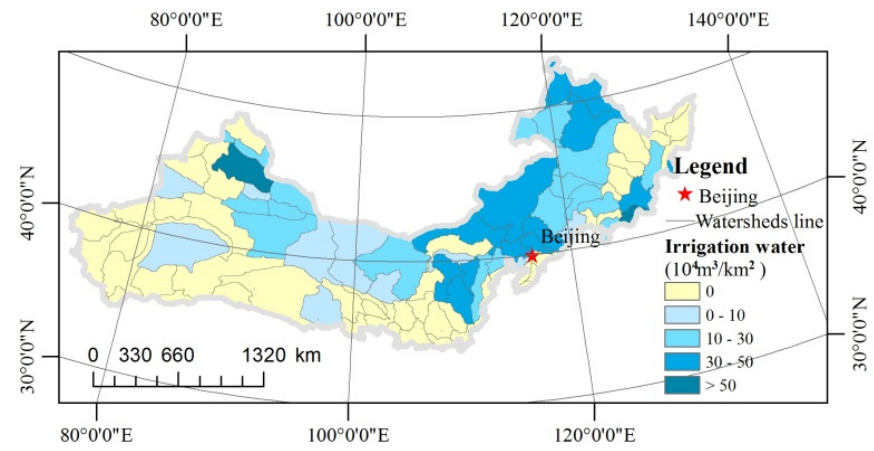

(c) irrigation water

Figure 5. Water supply (a), water consumption (b), and irrigation water (c) for green infrastructures of communities in the TNR.

Table 4. Threshold of the ecological water requirement for vegetation (EWR) among different climate zones.

\begin{tabular}{cccc}
\hline Climate Zones & Forest & Shrubs & Grassland \\
\hline Humid Medium Temperate Zone & 449.4 & 403.6 & 341.1 \\
Semi-humid Warm Temperate Zone & 454.3 & 414.2 & 353.3 \\
Semi-arid Temperate Zone & 381.5 & 350.5 & 259.4 \\
Arid Warm Temperate Zone & 351.7 & 288.2 & 187.9 \\
Arid Temperate Zone & 328.5 & 320.8 & 243.5 \\
Cold Temperate Zone & 396.4 & 366.6 & - \\
Qinghai-Tibet Alpine Zone & 340.5 & 320.7 & 230.8 \\
\hline
\end{tabular}

Note: The EWR threshold was determined using actual vegetation evapotranspiration at a $10 \%$ accumulation frequency among all grid cells from low to high for different types of vegetation in each climate zone. All EWR data are presented in $\mathrm{mm}$.

\subsection{Suitable Distribution of Vegetation Based on Precipitation}

Considering the EWRT of different vegetation and climate zones, the suitable vegetation distribution was determined with the LAPV. Excluding cropland, wetland, construction land, and barren land, the suitable vegetation with LAPV was calculated to be $1.84 \times 10^{6} \mathrm{~km}^{2}$, covering $40.92 \%$ of the total area in the TNR. There were $0.50 \times 10^{6} \mathrm{~km}^{2}$ of forests, $0.15 \times 10^{6} \mathrm{~km}^{2}$ of shrubs, and $1.19 \times 10^{6} \mathrm{~km}^{2}$ of grasslands.

With irrigation water for green infrastructures in communities, approximately $34,405 \mathrm{~km}^{2}$ of forests and $2030 \mathrm{~km}^{2}$ of shrubs could be constructed. Most of the green infrastructures are located in the southern part of the Inner Mongolia Plateau, Taihangshan Mountain, Hexi Corridor, and the southern foot of Tianshan Mountain (Figure 6). Although the direct water from precipitation is not enough to support forests and shrubs in these areas, it is crucial to develop forest and shrub areas to improve the living environment for local people. 


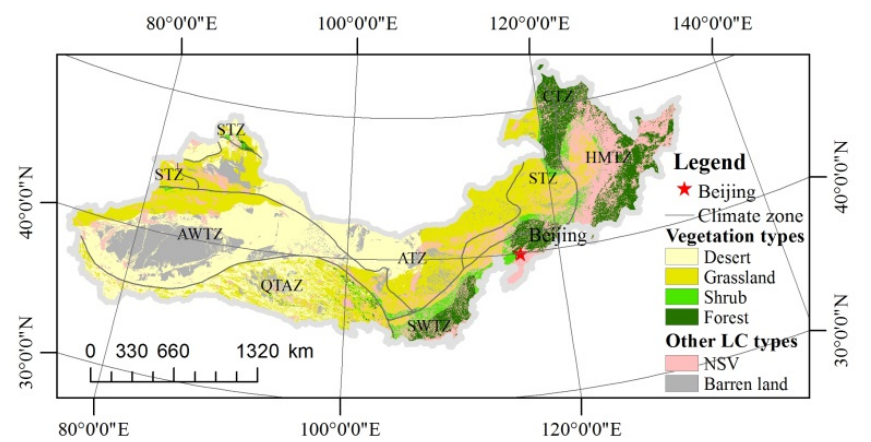

(a) Suitable vegetation distribution based on LAPV

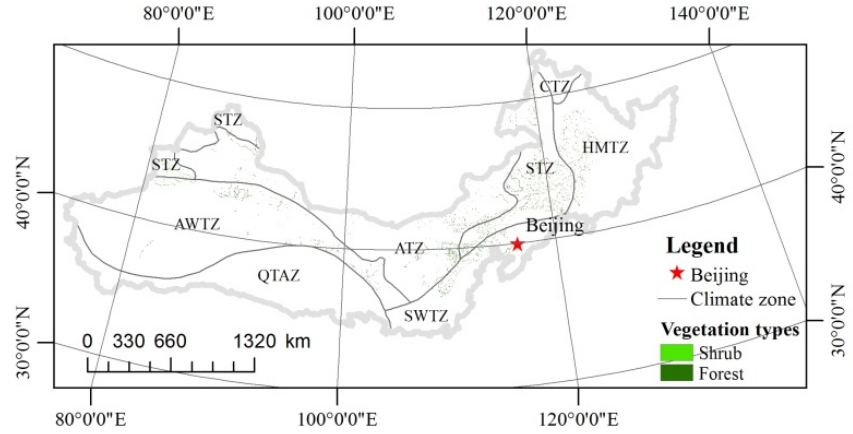

(b) Vegetation distribution based on irrigation water

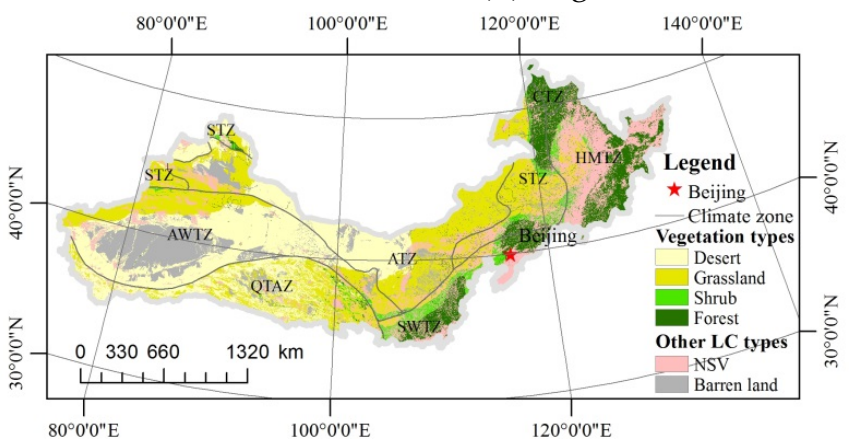

(c) Suitable vegetation distribution based on precipitation

Figure 6. Suitable vegetation distribution based on direct and indirect precipitation in the TNR. LC: land cover; NSV: not suitable for vegetation (including cropland, wetland, and construction land). (a). Suitable vegetation distribution based on LAPV was determined directly using LAPV and EWRT. (b). Vegetation distribution based on irrigation water was determined using surplus runoff from precipitation preferentially consumed by agriculture, industry, households, and the river ecological function and EWRT. (c). Suitable vegetation distribution based on precipitation was developed by integrating $(\mathbf{a}, \mathbf{b})$.

Integrating the suitable vegetation distribution with LAPV and irrigation water, the suitable vegetation distribution based on precipitation was estimated to be $1.84 \times 10^{6} \mathrm{~km}^{2}$, covering $41.01 \%$ of the total area in the TNR. The forest land was $0.54 \times 10^{6} \mathrm{~km}^{2}$, with a ratio of $11.99 \%$ to the total area in the TNR; the shrub land was $0.14 \times 10^{6} \mathrm{~km}^{2}$, with a ratio of $3.17 \%$; and the grassland was $1.16 \times 10^{6} \mathrm{~km}^{2}$, with a ratio of $25.84 \%$. The suitable forest area was mainly located in Northeast China, Yanshan Mountain, the south-eastern part of the Loess Plateau, and Altai Mountain. Suitable shrubs were situated in the transition zone between forest and grassland, especially in the south-eastern foot of Daxinganling Mountain, northern foot of Yanshan Mountain, and north-western part of the Loess Plateau (Figure 6).

\subsection{Suitability Assessment of Actual Vegetation}

Compared with the actual vegetation in the TNR, the suitable vegetation decreased slightly by $44.37 \times 10^{3} \mathrm{~km}^{2}$, and the vegetation ratio to the total area in the TNR was reduced by $0.99 \%$ (Table 5). The suitable forestland increased by $97.85 \times 10^{3} \mathrm{~km}^{2}$, the suitable shrubland increased by $14.45 \times 10^{3} \mathrm{~km}^{2}$, whereas the suitable grassland decreased by $156.67 \times 10^{3} \mathrm{~km}^{2}$ (Table 5). There was still potential for forests and shrubs to increase, mainly in the eastern and south-eastern parts of the TNR.

Table 5. Differences in area and coverage between actual vegetation and suitable vegetation.

\begin{tabular}{ccccccc}
\hline \multirow{2}{*}{ Vegetation Types } & \multicolumn{3}{c}{ Area $\left(\mathbf{1 0}^{\mathbf{3}} \mathbf{~ k m}^{\mathbf{2}}\right)$} & \multicolumn{3}{c}{ Vegetation Coverage (\%) } \\
\cline { 2 - 7 } & Actual Vegetation & Suitable Vegetation & Difference & Actual Vegetation & Suitable Vegetation & Difference \\
\hline Grassland & 1316.94 & 1160.27 & -156.67 & 29.33 & 25.84 & -3.49 \\
Shrubs & 128.09 & 142.54 & 14.45 & 2.85 & 3.17 & 0.32 \\
Forest & 440.62 & 538.48 & 97.85 & 9.81 & 11.99 & 2.18 \\
Sum & 1885.65 & 1841.29 & -44.37 & 42.00 & 41.01 & -0.99 \\
\hline
\end{tabular}


The paper also assessed the suitability of the actual vegetation. The results showed that $67.24 \%$ of the actual vegetation was the same as the suitable vegetation, signifying that much of the actual vegetation matched its available precipitation. Most of the actual forests and grasslands matched precipitation, while only $26.64 \%$ of shrubs matched its available precipitation. There was surplus precipitation for revegetation in $13.02 \%$ of the actual vegetation. The actual vegetation of $19.73 \%$ was overloaded to precipitation. For different vegetation types, $18.50 \%$ of the actual forests, $21.82 \%$ of the actual shrublands, and $19.95 \%$ of actual grasslands were overloaded to the precipitation (Table 6 and Figure 7). The overloaded status of vegetation in the TNR has been reported in other studies [25-27]. Wang et al. [25] indicated that most of the afforestation in Inner Mongolia suffered from water shortages, ranging from 74.6 to $609.9 \mathrm{~mm}$. Wang et al. [27] also showed that the area of forests distributed in unsuitable regions reached $7.31 \%$ of the entire Loess Plateau of China based on rainfall data. Zhang et al. [26] claimed that the carrying capacity for vegetation in Horqin, China, would decrease by $15 \%$ based on the leaf area index simulated with precipitation and other environmental factors. The overloaded vegetation can hardly provide any ecological and economic benefits and might exacerbate the water shortage in the long term, which should be addressed by the revegetation scheme in the TNSP in the future.

Table 6. Area and ratio of different matching types of actual vegetation.

\begin{tabular}{|c|c|c|c|}
\hline Actual Vegetation Types & Matching Types & Area $\left(10^{3} \mathrm{~km}^{2}\right)$ & Ratio (\%) \\
\hline \multirow{3}{*}{ Forest } & Matching & 359.11 & 81.50 \\
\hline & Overloaded & 81.52 & 18.50 \\
\hline & Sum & 440.62 & 100.00 \\
\hline \multirow{4}{*}{ Shrub } & Matching & 34.12 & 26.64 \\
\hline & Surplus & 66.02 & 51.54 \\
\hline & Overloaded & 27.95 & 21.82 \\
\hline & Sum & 128.09 & 100.00 \\
\hline \multirow{4}{*}{ Grassland } & Matching & 874.75 & 66.42 \\
\hline & Surplus & 179.52 & 13.63 \\
\hline & Overloaded & 262.67 & 19.95 \\
\hline & Sum & 1316.94 & 100.00 \\
\hline
\end{tabular}

In total

1885.65

Note: Matching refers to the actual vegetation being equal to the suitable vegetation; surplus refers to the EWR of the actual vegetation being less than the suitable vegetation, e.g., the actual vegetation is shrub while the suitable vegetation is forest; overloaded refers to the EWR of the actual vegetation being more than the suitable vegetation, e.g., the actual vegetation is forest while the suitable vegetation is grassland.

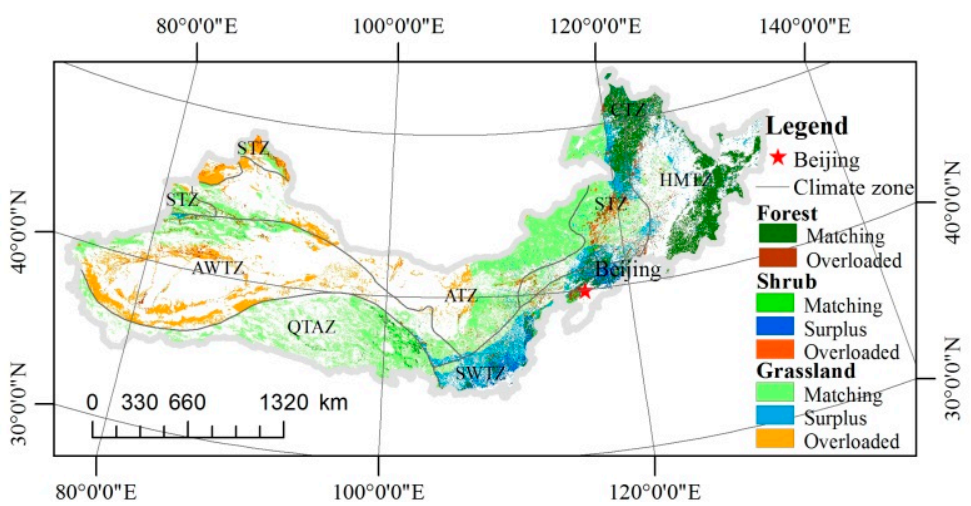

Figure 7. Suitability of actual vegetation. Matching refers to the actual vegetation being equal to the suitable vegetation; surplus refers to the EWR of the actual vegetation being less than the suitable vegetation, e.g., the actual vegetation is shrub while the suitable vegetation is forest; overloaded refers to the EWR of the actual vegetation being more than the suitable vegetation, e.g., the actual vegetation is forest while the suitable vegetation is grassland. 


\subsection{Optimizing Scheme of Revegetation in the TNR}

This research developed an optimization optimizing scheme for future revegetation in the TNR by contrasting the suitable and actual vegetation distributions in the TNR. The results indicate that the optimized area of revegetation in the TNR was calculated to be $3.04 \times 10^{6} \mathrm{~km}^{2}$. It includes $2.19 \times 10^{6} \mathrm{~km}^{2}$ of maintenance management type, $0.49 \times 10^{6} \mathrm{~km}^{2}$ of upgrade type, and $0.37 \times 10^{6} \mathrm{~km}^{2}$ of degradation type (Table 7).

Table 7. Revegetation of different types in the TNR.

\begin{tabular}{|c|c|c|c|}
\hline $\begin{array}{c}\text { Type of } \\
\text { Revegetation }\end{array}$ & Vegetation Type Change & Area $\left(10^{3} \mathrm{~km}^{2}\right)$ & Ratio (\%) \\
\hline \multirow{5}{*}{$\begin{array}{c}\text { Maintenance } \\
\text { management type }\end{array}$} & Forest & 359.11 & 11.80 \\
\hline & Shrub & 34.12 & 1.12 \\
\hline & Grassland & 874.75 & 28.75 \\
\hline & Desert & 917.27 & 30.14 \\
\hline & Sum & 2185.25 & 71.82 \\
\hline \multirow{7}{*}{ Upgrade type } & From shrub to forest & 66.02 & 2.17 \\
\hline & From grassland to forest & 103.28 & 3.39 \\
\hline & From desert to forest & 10.07 & 0.33 \\
\hline & From grassland to shrub & 76.24 & 2.51 \\
\hline & From desert to shrub & 7.10 & 0.23 \\
\hline & From desert to grassland & 222.77 & 7.32 \\
\hline & Sum & 485.49 & 15.95 \\
\hline \multirow{7}{*}{ Degradation type } & From forest to shrub & 25.08 & 0.82 \\
\hline & From forest to grassland & 42.67 & 1.40 \\
\hline & From shrub to grassland & 20.08 & 0.66 \\
\hline & From forest to desert & 13.77 & 0.45 \\
\hline & From shrub to desert & 7.87 & 0.26 \\
\hline & From grassland to desert & 262.67 & 8.63 \\
\hline & Sum & 372.13 & 12.23 \\
\hline & total & 3042.87 & 100.00 \\
\hline
\end{tabular}

Note: For maintenance management type, the most important practice was to limit human activities. For the upgrade type, actual vegetation develops into the vegetation types of higher EWR with a precipitation surplus by closure for vegetation, planting, seeding, etc. As the actual vegetation was unsustainable for the degradation type, the appropriate measure was to gradually return the vegetation types to those matching the available precipitation by stably stopping irrigation, felling prematurely ageing trees, planting suitable shrub of grass, etc.

The revegetation type of most areas in the TNR was maintenance management. There was $917.3 \times 10^{3} \mathrm{~km}^{2}$ of desert maintenance management type, mainly located in the western part of Inner Mongolia and eastern part of Xinjiang Province. Approximately $874.7 \times 10^{3} \mathrm{~km}^{2}$ of grassland maintenance management type was situated in the middle and eastern parts of Inner Mongolia, the Qinghai-Tibet Plateau, and Tianshan Mountain in Xinjiang Province. The area of forest maintenance management type was calculated to be $359.1 \times 10^{3} \mathrm{~km}^{2}$ and was especially distributed on Daxinganling Mountain, Xiaoxinganling Mountain, Changbaishan Mountain, Yanshan Mountain, and the Loess Plateau (Table 7 and Figure 8a).

The area of the upgrade type was much less than that of the maintenance management type. A desert of $222.8 \times 10^{3} \mathrm{~km}^{2}$ could be converted to grassland with grass reseeding, fly sowing grass, etc., mostly located in the Alxa High Plain, the southern foot of Tianshan Mountain, and the northern part of Xinjiang Province. Grasslands of $103.3 \times 10^{3} \mathrm{~km}^{2}$ could develop into the forests with afforestation, mostly situated in the southwestern foot of Daxinganling Mountain, Yanshan Mountain, and the Loess Plateau (Table 7 and Figure 8b).

Among all degradation types, the grassland area altered to the desert was estimated to be $262.7 \times 10^{3} \mathrm{~km}^{2}$, mostly located in Xinjiang Province and the western part of Inner Mongolia. Forests of $42.67 \times 10^{3} \mathrm{~km}^{2}$ should be converted to grassland, especially distributed in the Horqin Sand, the Bashang Plateau in Hebei Province, Inner Mongolia, and the southern foot of Tianshan Mountain (Table 7 and Figure 8c). 


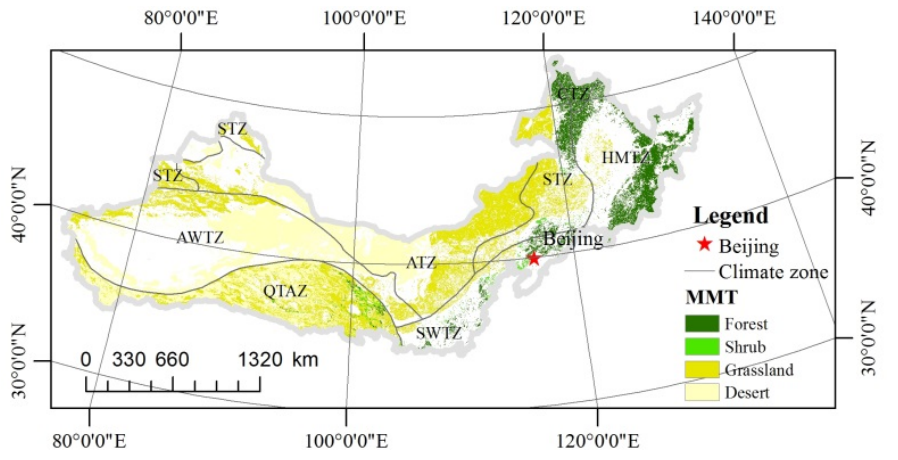

(a) Maintenance management type revegetation

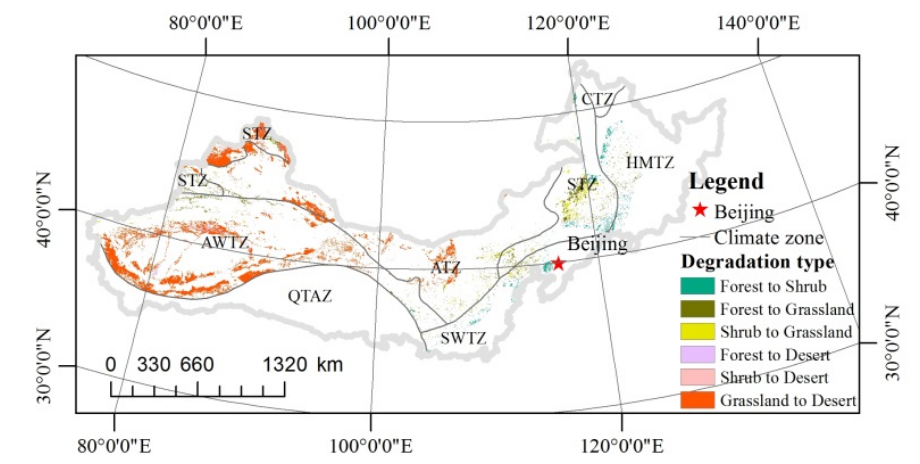

(c) Degradation type revegetation

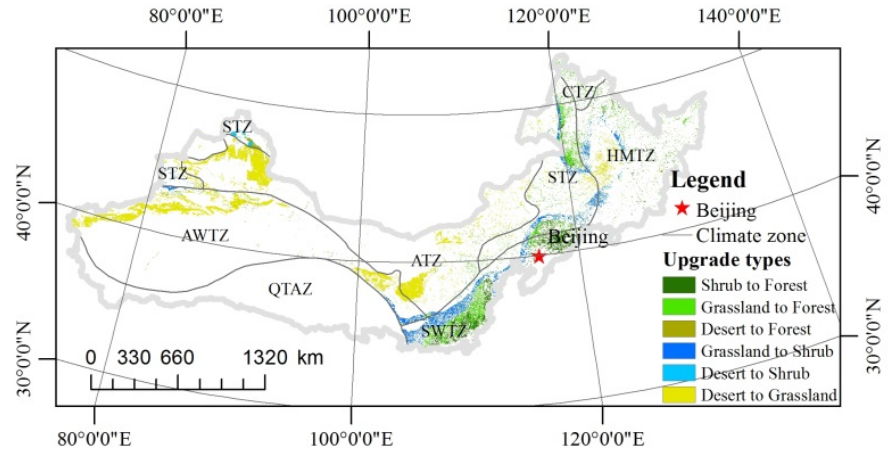

(b) Upgrade type revegetation

management type (a), upgrade type (b), and degradation type (c) revegetation

Figure 8. Spatial distribution of maintenance managem
in the TNR. MMT: maintenance management type.

With humid and semi-humid climates, the eastern and south-eastern parts of the TNR were covered with broad-leaf forest, needle-leaf forest, and mixed forest [74]. Most of the natural forest was converted to croplands, cities, towns, villages, roads, or plantations, and the remaining natural forest gradually degraded to a secondary forest, shrubland, grassland, or desert as human activities increased [75,76]. The shrubland, grassland, and desert in the eastern and south-eastern parts of the TNR could be restored to forests engineering practices, plantations, enclosures to limit human disturbances, etc. A few studies claimed that vegetation gain was observed in the humid and semi-humid climate regions of the TNR $[77,78]$, and the contribution of human intervention could not be neglected. There is still a large quantity of shrubs and grassland in the humid and semi-humid climate regions of the TNR, which supports the potential for forest revegetation $[79,80]$. However, human disturbances would be a major challenge for forest restoration. It would take a long time for trees to grow into a forest. In addition, Zhang et al. [26] indicated that the carrying capacity for vegetation in semiarid areas in the TNR, such as Junggar and Mu Us, would increase in the future based on precipitation and other environmental factors. The significantly increasing trend of precipitation since the 1950s in the western part of the TNR would promote revegetation [81].

Afforestation has been proposed as a strategy to mitigate environmental degradation to improve agricultural production, prevent soil erosion by water and wind, and increase the income of local people in the TNR since 1978 [54,82]. Before 2010, tree or shrub planting was preferable in the TNSP because people would receive higher payments [83]. Additionally, the government urged people to plant more trees and shrubs to reach the goal of the forest cover rate [31]. Water shortages in arid and semiarid regions were neglected. This resulted in a low survival rate of trees, unstable ecosystems, inefficient labor, and wasted investments [18,84-86]. Therefore, it became impractical to meet the intended forest cover goal. It is crucial to adjust the strategy according to precipitation in the TNR. Afforestation should not be the only option for revegetation. According to our study, the most widely adopted practice in the TNR should be natural restoration. Referring to precipitation, some 
types of vegetation can be transformed into vegetation with lower EWR, such as from forest to shrubland or from shrubland to grassland. This optimization scheme would help develop stable ecosystems, facilitate consistent delivery of ecosystem services, and mitigate the passive effects of revegetation on the hydrologic cycle in the TNR.

\section{Conclusions}

This study assessed the suitability of actual vegetation in the TNR and provided suggestions for the revegetation of the TNSP in the future. First, this article indicated that $67.24 \%$ of the actual vegetation matched the suitable vegetation, while $18.50 \%$ of the actual forest, $21.82 \%$ of the actual shrubland, and $19.95 \%$ of the actual grassland were overloaded. Secondly, it supported the optimization scheme for the TNSP, including maintenance management type of $2.19 \times 10^{6} \mathrm{~km}^{2}$, upgrade type of $0.49 \times 10^{6} \mathrm{~km}^{2}$, and degradation type of $0.37 \times 10^{6} \mathrm{~km}^{2}$.

The results of this paper provided important policy-making implications for the governmental implementation of the TNSP in the next 30 years. The available precipitation for vegetation should be considered the most important principle for the revegetation of the TNSP. The optimization scheme for the TNSP was based on the available precipitation for vegetation at the pixel level, which could support and provide guidance for the government to implement the TNSP. There is still some potential for forest and shrubland growth, mostly located in the eastern and south-eastern parts of the TNR. Comparing the actual vegetation and suitable vegetation, approximately $0.37 \times 10^{6} \mathrm{~km}^{2}$ of vegetation should be degraded into vegetation types matching their available precipitation, including forest to shrubs, grassland, or desert, and shrubs to grassland or desert. This has not been proposed as an option for the TNSP before. This would be a preferable choice for governments that can no longer afford plantation irrigation fees. This study also recognized maintenance management (natural restoration) as an important practice of revegetation in the TNR. The optimization scheme would contribute to achieving the target of increasing vegetation cover in the TNR, constructing stable ecosystems, and mitigating the depletion of groundwater.

However, there were some uncertainties in our study. The precipitation data from the meteorological stations were interpolated without considering the effects of topography, which would affect the accuracy of suitable vegetation distribution. According to our study, much vegetation in Xinjiang Province should be degraded into a type with less EWR, such as from forest to grassland and from grassland to desert. Some of this mismatch between actual and suitable vegetation in Xinjiang Province included two types: vegetation surviving with irrigation [86], which should be restored, and vegetation surviving from snowmelt and glaciers, which need not be restored [87]. This uncertainty would be clarified only with the field investigation on the sources of vegetation available water. In addition, all of the vegetation in the Qinghai-Tibet alpine zone fell into the maintenance management type because of its high vulnerability $[88,89]$. The optimization scheme of vegetation in the Qinghai-Tibet alpine zone should be developed with much more prudent investigation in the future, such as through surveys on vegetation and their water requirements by vegetation zone, topography, altitude, etc.

Author Contributions: Conceptualization, G.X. and Y.X.; methodology, G.X., Y.X. and C.L.; software, J.X., Y.L., K.Q. and J.L. (Jingya Liu); validation, C.Z. (Changshun Zhang); formal analysis, J.X., Y.L. and C.X.; investigation, Y.W., S.G. and L.G.; resources, G.X.; data curation, J.X., C.Z. (Changshun Zhang), J.L. (Jingya Liu), Y.W., S.G., J.L. and L.G.; writing-original draft preparation, Y.X.; writing-review and editing, G.X.; visualization, Y.X.; supervision, G.X.; project administration, C.Z. (Caixia Zhang); funding acquisition, G.X. All authors have read and agreed to the published version of the manuscript.

Funding: This work was funded by the National Natural Science Foundation of China (41971272), the Strategic Priority Research Program of Chinese Academy of Sciences (XDA20020402), Guangxi Science and Technology Major Project (AA20161002-3), the Science and Technology Program of Guizhou Province ([2019]1218, [2019]1222, [2020]1Z031).

Institutional Review Board Statement: Not applicable. 
Informed Consent Statement: Not applicable.

Data Availability Statement: All data in this study were correctly referenced. The meteorological datasets were obtained from the National Meteorological Information Centre of China (http:/ / data. $\mathrm{cma} . \mathrm{cn} /, 15 / 06 / 2019)$. The land use/cover data of $1 \times 1 \mathrm{~km}$ resolution in the TNR in 2015 was from the Chinese Land Use Change Database (CLUSD) [35]. The SRTM 90 m DEM data can be found on this website (http:/ / srtm.csi.cgiar.org, accessed on 1 July 2019). Hydrological Frequency Distribution Curve Fitting software (HFDCF, teaching version) can be downloaded from this website (http:/ / www.opdown.com/soft/92165.html, accessed on 10 July 2019).

Conflicts of Interest: The authors declare no conflict of interest.

\section{References}

1. Baer, N.W. Shelterbelts and Windbreaks in the Great Plains. J. For. 1989, 87, 32-36.

2. Brain, S. The Great Stalin Plan for the Transformation of Nature. Environ. Hist. 2010, 15, 670-700. [CrossRef]

3. Pausata, F.S.R.; Gaetani, M.; Messori, G.; Berg, A.; Maia de Souza, D.; Sage, R.F.; deMenocal, P.B. The Greening of the Sahara: Past Changes and Future Implications. One Earth 2020, 2, 235-250. [CrossRef]

4. Goffner, D.; Sinare, H.; Gordon, L. The Great Green Wall for the Sahara and the Sahel Initiative as an opportunity to enhance resilience in Sahelian landscapes and livelihoods. Reg. Environ. Chang. 2019, 19, 1417-1428. [CrossRef]

5. Zhang, C.; Wang, X.; Li, J.; Hua, T. Identifying the effect of climate change on desertification in northern China via trend analysis of potential evapotranspiration and precipitation. Ecol. Indic. 2020, 112, 106141. [CrossRef]

6. Xu, D.; Ding, X. Assessing the impact of desertification dynamics on regional ecosystem service value in North China from 1981 to 2010. Ecosyst. Serv. 2018, 30, 172-180. [CrossRef]

7. Zhang, Z.; Huisingh, D. Combating desertification in China: Monitoring, control, management and revegetation. J. Clean. Prod. 2018, 182, 765-775. [CrossRef]

8. Na, R.; Du, H.; Na, L.; Shan, Y.; He, H.S.; Wu, Z.; Zong, S.; Yang, Y.; Huang, L. Spatiotemporal changes in the Aeolian desertification of Hulunbuir Grassland and its driving factors in China during 1980-2015. Catena 2019, 182, 104123. [CrossRef]

9. Shao, Y.; Zhang, Y.; Wu, X.; Bourque, C.P.A.; Zhang, J.; Qin, S.; Wu, B. Relating historical vegetation cover to aridity patterns in the greater desert region of northern China: Implications to planned and existing restoration projects. Ecol. Indic. 2018, 89, 528-537. [CrossRef]

10. Wen, X.; Deng, X.; Zhang, F. Scale effects of vegetation restoration on soil and water conservation in a semi-arid region in China: Resources conservation and sustainable management. Resour. Conserv. Recycl. 2019, 151, 104474. [CrossRef]

11. Chu, X.; Zhan, J.; Li, Z.; Zhang, F.; Qi, W. Assessment on forest carbon sequestration in the Three-North Shelterbelt Program region, China. J. Clean. Prod. 2019, 215, 382-389. [CrossRef]

12. Wang, X.; Yin, L.; Xiao, F.; Zhang, M.; Liu, L.; Zhou, Z.; Ao, Y. The desertification process in the Silk Road Economic Belt in the past 15 years: A study using MODIS data and GIS analysis. Geol. J. 2018, 53, 322-331. [CrossRef]

13. Gerlein-Safdi, C.; Keppel-Aleks, G.; Wang, F.; Frolking, S.; Mauzerall, D.L. Satellite monitoring of natural reforestation efforts in China's drylands. One Earth 2020, 2, 98-108. [CrossRef]

14. Cao, S.; Suo, X.; Xia, C. Payoff from afforestation under the Three-North Shelter Forest Program. J. Clean. Prod. 2020, $256,120461$. [CrossRef]

15. Zheng, X.; Zhu, J.; Xing, Z. Assessment of the effects of shelterbelts on crop yields at the regional scale in Northeast China. Agric. Syst. 2016, 143, 49-60. [CrossRef]

16. Deng, C.; Zhang, B.; Cheng, L.; Hu, L.; Chen, F. Vegetation dynamics and their effects on surface water-energy balance over the Three-North Region of China. Agric. For. Meteorol. 2019, 275, 79-90. [CrossRef]

17. Duan, H.; Yan, C.; Tsunekawa, A.; Song, X.; Li, S.; Xie, J. Assessing vegetation dynamics in the Three-North Shelter Forest region of China using AVHRR NDVI data. Environ. Earth Sci. 2011, 64, 1011-1020. [CrossRef]

18. Zhu, J.; Zheng, X. The prospects of development of the Three-North Afforestation Program (TNAP): On the basis of the results of the 40-year construction general assessment of the TNAP. Chin. J. Ecol. 2019, 38, 1600-1610, (In Chinese with English abstract).

19. Wang, X.M.; Zhang, C.X.; Hasi, E.; Dong, Z.B. Has the Three Norths Forest Shelterbelt Program solved the desertification and dust storm problems in arid and semiarid China? J. Arid Environ. 2010, 74, 13-22. [CrossRef]

20. Zheng, X.; Zhu, J.J.; Yan, Q.L.; Song, L.N. Effects of land use changes on the groundwater table and the decline of Pinus sylvestris var. mongolica plantations in southern Horqin Sandy Land, Northeast China. Agric. Water Manag. 2012, 109, 94-106. [CrossRef]

21. Wu, S.H.; Chao, C.T.; Huang, B.H.; Luo, M.X.; Duan, X.G.; Liao, P.C. Environmental disturbance in natural forest and the effect of afforestation methods on timber volume increment in Pinus sylvestris L. var. mongolica Litv. Glob. Ecol. Conserv. 2020, 24 , e01311. [CrossRef]

22. Ge, J.; Pitman, A.; Guo, W.; Zan, B.; Fu, C. Impact of revegetation of the Loess Plateau of China on the regional growing season water balance. Hydrol. Earth Syst. Sci. 2020, 24, 515-533. [CrossRef]

23. Jia, Y.H.; Shao, M.A. Dynamics of deep soil moisture in response to vegetational restoration on the Loess Plateau of China. J. Hydrol. 2014, 519, 523-531. [CrossRef] 
24. Wang, L.; D'Odorico, P. Water limitations to large-scale desert agroforestry projects for carbon sequestration. Proc. Natl. Acad. Sci. USA 2019, 116, 24925-24926. [CrossRef]

25. Wang, Z.; Peng, D.; Xu, D.; Zhang, X.; Zhang, Y. Assessing the water footprint of afforestation in Inner Mongolia, China. J. Arid Environ. 2020, 182, 104257. [CrossRef]

26. Zhang, J.; Zhang, Y.; Qin, S.; Wu, B.; Ding, G.; Wu, X.; Gao, Y.; Zhu, Y. Carrying capacity for vegetation across northern China drylands. Sci. Total Environ. 2020, 710, 136391. [CrossRef]

27. Wang, C.; Wang, S.; Fu, B.; Lü, Y.; Liu, Y.; Wu, X. Integrating vegetation suitability in sustainable revegetation for the Loess Plateau, China. Sci. Total Environ. 2021, 759, 143572. [CrossRef]

28. Feng, X.; Fu, B.; Piao, S.; Wang, S.; Ciais, P.; Zeng, Z.; Lü, Y.; Zeng, Y.; Li, Y.; Jiang, X.; et al. Revegetation in China's Loess Plateau is approaching sustainable water resource limits. Nat. Clim. Chang. 2016, 6, 1019-1022. [CrossRef]

29. Cao, S.; Chen, L.; Shankman, D.; Wang, C.; Wang, X.; Zhang, H. Excessive reliance on afforestation in China's arid and semi-arid regions: Lessons in ecological restoration. Earth-Sci. Rev. 2011, 104, 240-245. [CrossRef]

30. Liu, F.; Zhang, Z.; Zhao, X.; Wang, X.; Zuo, L.; Wen, Q.; Yi, L.; Xu, J.; Hu, S.; Liu, B. Chinese cropland losses due to urban expansion in the past four decades. Sci. Total Environ. 2019, 650, 847-857. [CrossRef] [PubMed]

31. NFGA. The 40-Year Development Report on the Construction of the Three North Shelterbelt Program (1978-2018); China Forestry Press: Beijing, China, 2019; (In Chinese with English abstract).

32. Wan, B.; Gao, S.; Fu, X.; Ji, C. Practical research on L-moment method of hydrologic frequency analysis. China Rural Water Hydrop. 2009, 6, 63-66, (In Chinese with English abstract).

33. Guttman, N.B. Accepting the standardized precipitation index: A calculation algorithm. J. Am. Water Resour. Assoc. 1999, 35, 311-322. [CrossRef]

34. Box, G.E.P.; Jenkins, G.M. Time Series Analysis, Forecasting and Control; Holden Day: San Francisco, CA, USA, 1976.

35. Zhang, G.; Su, X.; Ayantobo, O.O.; Feng, K.; Guo, J. Spatial interpolation of daily precipitation based on modified ADW method for gauge-scarce mountainous regions: A case study in the Shiyang River Basin. Atmos. Res. 2021, 247, 105167. [CrossRef]

36. Biswas, S.K.; Chandrasekar, V. Cross-Validation of Observations between the GPM Dual-Frequency Precipitation Radar and Ground Based Dual-Polarization Radars. Remote Sens. 2018, 10, 1773. [CrossRef]

37. Soltani, S.S.; Ataie-Ashtiani, B.; Danesh-Yazdi, M.; Simmons, C.T. A probabilistic framework for water budget estimation in low runoff regions: A case study of the central Basin of Iran. J. Hydrol. 2020, 586, 124898. [CrossRef]

38. Munier, S.; Aires, F. A new global method of satellite dataset merging and quality characterization constrained by the terrestrial water budget. Remote Sens. Environ. 2018, 205, 119-130. [CrossRef]

39. Baffaut, C.; Baker, J.M.; Biederman, J.A.; Bosch, D.D.; Brooks, E.S.; Buda, A.R.; Demaria, E.M.; Elias, E.H.; Flerchinger, G.N.; Goodrich, D.C.; et al. Comparative analysis of water budgets across the U.S. long-term agroecosystem research network. J. Hydrol. 2020, 588, 125021. [CrossRef]

40. Oliver, J.E. Evapotranspiration. In Climatology; Springer: Boston, MA, USA, 1987; pp. 449-456.

41. Liu, S.; Wen, Y.; Wang, B.; Zhou, G. Laws of Hydrological and Ecological Functions of Chinese Forest Ecosystems; China Forestry Publishing House: Beijing, China, 1996; (In Chinese with English abstract).

42. Yang, H.; Sun, L.; Yu, X. Study of the water balance for soil and water conservation in forests of Northwest Shanxi Province. J. Beijing For. Univ. 1993, 15, 42-50, (In Chinese with English abstract).

43. Zhu, J.; Zhu, Q.; Zhang, J.; Bi, H.; Wei, T.; Zhang, X. China Ecosystem Positioning Observation and Research Dataset Forest Ecosystem Volume Shanxi Jixian Station; China Agriculture Press: Beijing, China, 2010; (In Chinese with English abstract).

44. Zhang, X.; Sun, Z.; Zhang, X. Analysis on the function of different stand affection runoff and sediment from rainstorm in gullied Loess Hill of Jinxi. J. Soil Water Conserv. 2003, 1, 37-42, (In Chinese with English abstract).

45. Jiang, J. Research on Dynamic Characters of Soil Moisture and Water Balance of Forest Land in Nanxiaohe Gou Basin. Master's Thesis, Xi'an University of Technology, Xi'an, China, 2008. (In Chinese with English abstract).

46. Wang, Y. The Hydrological Impacts of Typical Forests and Their Slope Scale Effects at the South Side of Liupan Mountains. Ph.D. Thesis, Chinese Academy of Forestry, Beijing, China, 2015. (In Chinese with English abstract).

47. Li, H.; Zhang, X.; Zhang, Y.; Han, Z.; Li, X.; Lu, J. Study on water resource conservation of natural spruce forest ecosystem based on month water balance in the Middle Tianshan Mountains. J. Soil Water Conserv. 2011, 25, 227-232, (In Chinese with English abstract).

48. Zhu, J.; Shi, J. The Hydrological effect of broadleaved Korean Pine forest in Hsingan Mountains of North-Eastern China. J. North-East. For. Inst. 1982, 4, 37-44, (In Chinese with English abstract).

49. Cai, T.; Liu, Q.; Wang, L.; Yang, W. The balance of the soil water in Dahurian Larch plantation. J. North-East For. Univ. 1996, 24, 62-67, (In Chinese with English abstract).

50. Wei, X.; Zhou, X. Study on relation between water cycling and nutrient cycling in oak forest ecosystem. Rural Eco-Environ. 1993, 9, 1-5, (In Chinese with English abstract).

51. Duan, W.; Liu, S. Analysis on runoff and sediment yields of water conservation forests in Lianhua Lake Reservoir Area. J. Soil Water Conserv. 2006, 20, 12-15, (In Chinese with English abstract).

52. Wen, J. Forest Land Evapotrspiration and Water Balance of Songhua River Water Conservation Forest. Master's Thesis, Northeast Forestry University, Harbin, China, 2007. (In Chinese with English abstract). 
53. Ding, B.; Sun, J. Studies on biological productivity and nutrient cycling of artificial forest ecosystem of Korena Pine. J. North-East For. Univ. 1989, 17, 1-98, (In Chinese with English abstract).

54. Jiang, P.; Guo, F.; Luo, Y.; Wei, J.; Sun, X.; Wu, G. Water and soil conservation function of typical plantation ecosystem in semi-arid region of Western Liaoning Province. Chinese J. Appl. Ecol. 2007, 18, 2905-2909, (In Chinese with English abstract).

55. Zhou, H.; Wang, D.; Ma, J.; Jin, F.; Yin, X. Impacts of grass coverage and rainfall intensity on runoff and sediment yield in Tianshan Mountains of China: A case study of the Tianchi Natural Lake Reserve Area. Bull. Soil Water Conserv. 2009, 29, 26-29, (In Chinese with English abstract).

56. Cheng, X. Water Transformation and Simulation of Soil-Artificial Vegetation-Atmosphere-Transer in the Farming-Pastoral Zone of the Loess Plateau. Ph.D. Thesis, Graduate University of Chinese Academy of Sciences, Yangling, China, 2008. (In Chinese with English abstract).

57. Wang, Y.; Yun, W.; Miao, B.; Liang, C.; Wang, W. The pattern and dynamics of surface runoff in the typical steppe of Inner Mongolia. Res. Soil Water Conserv. 2008, 15, 114-117,122, (In Chinese with English abstract).

58. Feng, W. Soil Moisture Dynamics and Deep Soil Layer Infiltration Process in Northeastern Margin of Mu Us Sandland. Ph.D. Thesis, Chinese Academy of Forestry, Beijing, China, 2015. (In Chinese with English abstract).

59. Zhang, S. Study on Ecohydrological Model and Evolution Law in Hungriness Area of Northern Shaanxi. Master's Thesis, Xi'an University of Technology, Xi'an, China, 2018. (In Chinese with English abstract).

60. Zhou, M. Research on the Hydrological Process and Laws of Larix Gmelini Ecosystem at the Greater Xingan Mountains. Ph.D. Thesis, Beijing Forestry University, Beijing, China, 2003. (In Chinese with English abstract).

61. Liu, G. Studies on Soil Moisture and Runoff Generation/Infiltration Under Typical Grasslands in the Upper Reach of the Heihe River. Master's Thesis, Lanzhou University, Lanzhou, China, 2016. (In Chinese with English abstract).

62. Ren, Q. Study on the Balance of Water and Heat in Secondary Birch Forest. Master's Thesis, Northeast Forestry University, Harbin, China, 1989. (In Chinese with English abstract).

63. Zhu, C. Water Balance and Forest Management of Watershed in Nenjiang Upriver. Master's Thesis, Northeast Forestry Univerisy, Harbin, China, 2001. (In Chinese with English abstract).

64. Gao, R. Water balance of major forest types in East Liaoning Mountainous Region. Bull. Soil Water Conserv. 2002, 22, 5-8, (In Chinese with English abstract).

65. Sui, Y.; Xu, X.; Zhang, Y.; Liu, Y.; Zhao, S.; Yan, B. Analysis of water balance in sloping land and forest land in the low mountain and mound area in Mid-eastern Jilin Province: A case study of Xingmu Small Watershed in Dongliao County. Res. Soil Water Conserv. 2014, 21, 197-200,207, (In Chinese with English abstract).

66. Zou, S. The Runoff Process in the Small Watershed of the Typical Steppe Region in Inner Mongolia Province. Master's Thesis, Inner Mongolia Agricultural University, Hohhot, China, 2012. (In Chinese with English abstract).

67. Zhao, M.; Yao, W.; Wang, J.; Xiao, P. Experimental study on influence of vegetation coverage to soil infiltration and runoffproducing of the Loess Plateau Region. Soil Water Conserv. China 2015, 6, 41-43,67, (In Chinese with English abstract).

68. Wang, J. Study of Mechanism and Process of Water Transmission on Water Resource Conservation Forests Ecosystem in Qilian Mountains. Ph.D. Thesis, Central South University, Changsha, China, 2006. (In Chinese with English abstract).

69. Han, Q.; Tan, G.; Fu, X.; Yang, H.; Li, X. Calculation methods of river environmental flow and their applications. Eng. J. Wuhan Univ. 2018, 51, 189-197, (In Chinese with English abstract).

70. Sharp, R.; Douglass, J.; Wolny, S.; Arkema, K.; Bernhardt, J.; Bierbower, W.; Chaumont, N.; Denu, D.; Fisher, D.; Glowinski, K.; et al. VEST 3.9.0.post51+ug.g22f67b0 User's Guide; The Natural Capital Project, Stanford University, University of Minnesota, The Nature Conservancy, World Wildlife Fund: Stanford, CA, USA, 2020.

71. Li, D.; Wu, S.; Liu, L.; Liang, Z.; Li, S. Evaluating regional water security through a freshwater ecosystem service flow model: A case study in Beijing-Tianjian-Hebei region, China. Ecol. Indic. 2017, 81, 159-170. [CrossRef]

72. Fu, B. On the calculation of evaporation from land surface. Sci. Atmos. Sin. 1981, 5, 23-31, (In Chinese with English abstract).

73. Penman, H.L. Natural evaporation from open water, bare soil, and grass. Proc. Roy. Soc. A-Math. Phy. 1948, 193, $120-145$.

74. Wu, Z. Vegetation in China; China Science Publishing: Beijing, China, 1995; (In Chinese with English abstract).

75. Wang, H.; Sun, B.; Yu, X.; Xin, Z.; Jia, G. The driver-pattern-effect connection of vegetation dynamics in the transition area between semi-arid and semi-humid northern China. Catena 2020, 194, 104713. [CrossRef]

76. Cui, X.; Jin, X.; Zhou, Y.; He, B.; Miao, L.; Zhu, F.; Yang, X.; Lin, Y.; Han, J.; Wang, H.; et al. Land-Use Changes in China During the Past 300 Years. In Land-Use Changes in China; World Scientific Publishing: Singapore, 2015; pp. 1-10.

77. Zhang, Y.; Peng, C.; Li, W.; Tian, L.; Zhu, Q.; Chen, H.; Fang, X.; Zhang, G.; Liu, G.; Mu, X.; et al. Multiple afforestation programs accelerate the greenness in the 'Three North' region of China from 1982 to 2013. Ecol. Indic. 2016, 61, 404-412. [CrossRef]

78. Qiu, B.; Chen, G.; Tang, Z.; Lu, D.; Wang, Z.; Chen, C. Assessing the Three-North Shelter Forest Program in China by a novel framework for characterizing vegetation changes. ISPRS J. Photogramm. Remote Sens. 2017, 133, 75-88. [CrossRef]

79. Zhang, D.; Zuo, X.; Zang, C. Assessment of future potential carbon sequestration and water consumption in the construction area of the Three-North Shelterbelt Programme in China. Agric. For. Meteorol. 2021, 303, 108377. [CrossRef]

80. Duo, A.; Zhao, W.; Qu, X.; Jing, R.; Xiong, K. Spatio-temporal variation of vegetation coverage and its response to climate change in North China plain in the last 33 years. Int. J. Appl. Earth Obs. Geoinf. 2016, 53, 103-117. 
81. Deng, O.; Li, Y.; Lu, C.; Xiao, Y.; Li, R. Examination and prediction of long time precipitation series and multi-scaled variation trend of precipitation in Three North Shelterbelt Forest Program region. Acta Ecol. Sin. 2020, 40, 8707-8716, (In Chinese with English abstract).

82. Li, X.; Liu, L.; Xie, J.; Wang, Z.; Yang, S.; Zhang, Z.; Qi, S.; Li, Y. Optimizing the quantity and spatial patterns of farmland shelter forests increases cotton productivity in arid lands. Agric. Ecosyst. Environ. 2020, 292, 106832. [CrossRef]

83. Guo, T.; Wang, C. A review of the construction of the Three North Shelterbelt System in the past 20 years. Green China 1998, 6 , 1-13, (In Chinese with English abstract).

84. Lu, C.; Zhao, T.; Shi, X.; Cao, S. Ecological restoration by afforestation may increase groundwater depth and create potentially large ecological and water opportunity costs in arid and semiarid China. J. Clean. Prod. 2018, 176, 1213-1222. [CrossRef]

85. Zastrow, M. China's tree-planting drive could falter in a warming world. Nature 2019, 573, 474-475. [CrossRef] [PubMed]

86. Zhou, M. Planting and management techniques of Amorpha pseudoacacia introduced in barren hills in Korla. J. Green Sci. Technol. 2019, 2, 116-117, (In Chinese with English abstract).

87. Chen, H.; Chen, Y.; Li, W.; Li, Z. Quantifying the contributions of snow/glacier meltwater to river runoff in the Tianshan Mountains, Central Asia. Glob. Planet. Chang. 2019, 174, 47-57. [CrossRef]

88. Xia, M.; Jia, K.; Zhao, W.; Liu, S.; Wei, X.; Wang, B. Spatio-temporal changes of ecological vulnerability across the Qinghai-Tibetan Plateau. Ecol. Indic. 2021, 123, 107274. [CrossRef]

89. Zhao, Y.; Chen, D.; Fan, J. Sustainable development problems and countermeasures: A case study of the Qinghai-Tibet Plateau. Geogr. Sustain. 2020, 1, 275-283. [CrossRef] 